\title{
Spodbujanje ustvarjalnosti in inovativnosti
}

\author{
Rajko Zakšek* \\ Fakulteta za organizacijske študije v Novem mestu, Novi trg 5, 8000 Novo mesto, Slovenija \\ rajko.zaksek@fos.unm.si \\ Bojan Krajnc \\ Fakulteta za organizacijske študije v Novem mestu, Novi trg 5, 8000 Novo mesto, Slovenija \\ bojan.krajnc@fos.unm.si
}

\begin{abstract}
Povzetek:
Raziskovalno vprašanje (RV): Ali organizacije spodbujajo ustvarjalnost in inovativnost, ki lahko močno vplivata na izdelke in hkrati na poslovanje organizacije?

Namen: Ugotoviti in analizirati oceno temeljnega gradnika modela odličnosti EFQM ustvarjalnost in inovativnost. Na osnovi ugotovitev podati predloge za izboljšavo.

Metoda: Uporaba kvalitativne metode, pregled strokovne in znanstvene literature, uporaba raziskovalne metode $\mathrm{z}$ analitičnim razčlenjevanjem ter iz njih izluščili bistvo in ugotovitve.

Rezultati: Rezultati so pokazali, da imajo organizacije dobro razvito inovativno in ustvarjalno dejavnost, vendar je trend pri vseh ocenjevalnih gradnikih modela odličnosti EFQM negativen, zato smo podali predloge za izboljšave. Prav tako je ocena gradnika lasnega podjetja zadovoljiva. Vsa preučena strokovna literatura navaja poglavitne aktivnosti, ki so potrebne za nenehno izboljševanje ustvarjalnosti in inovativnosti v organizacijah.

Organizacija: Raziskava ima na organizacije velik vpliv, saj smo z oceno gradnikov odličnosti EFQM na področju ustvarjalnosti in inovativnosti dobili izhodišče k spremembam.

Družba: Z raziskavo želimo opozoriti, da je to področje zelo pomembno, zato je potrebno $v$ prihodnosti še veliko vanj vložiti, da bodo sadovi ustvarjalnosti in inovativnosti vedno odlično obrodili.

Originalnost: Prispevek stroki je v izvirnosti raziskave. Da bi bila raziskava spodbujanja ustvarjalnosti in inovativnosti prikazana skozi gradnike odličnosti EFQM še nismo zasledili. Omejitve/nadaljnje raziskovanje: Raziskava je omejena le en gradnik s sedmimi podgradniki EFQM. Smiselno bi bilo izdelati primerjalne analize različnih podjetij. V nadaljevanju bi lahko preučili vpliv ustvarjalnosti in inovativnosti na produktivnost $\mathrm{v}$ organizaciji
\end{abstract}

Ključne besede: ustvarjalnost, inovativnost, organizacija, inovacija, gospodarska korist, zadovoljstvo zaposlenih, spodbujanje zaposlenih.

\section{Uvod}

Organizacije, katere želijo biti na trgu učinkovite in uspešne morajo znati izkoristiti sadove ustvarjalnosti in inovativnosti, pri vseh zaposlenih. 
Marec 2021, leto / year 10, številka / number 1, str. / pp. 26-40.

Spodbujanje ustvarjalnosti in inovativnosti je sicer v organizacijah in podjetjih že dolgo znan fenomen, ki se povezuje z različnimi koncepti upravljanja in vodenja podjetja, kot so učeča se organizacija, mentorsko vodenje, spodbujanje inovativnosti, vseživljenjsko učenje. Ključnega pomena ima tudi klima $v$ organizaciji na kar vplivajo tako menedžerji, vodstvo, kooperanti kot tudi vsi zaposleni.

Raziskava je zastavljena z ciljem pregleda doseženih ocen gradnikov odličnosti EFQM glede ustvarjalnosti in inovativnosti in na osnovi ugotovitev pa podati predloge za izboljšavo.

V raziskavo je vključeno več organizacij, ki se med seboj razlikujejo po dejavnosti, število zaposlenih, lokaciji.

Znano je, da imajo posamezne organizacije različne načine spodbujanja ustvarjalnosti in inovativnosti. V strokovni literaturi je zaslediti, da vse več podjetij vlaga v zamisli, ideje, inovacije v svojem okolju, saj se zavedajo pomembnosti in priložnosti poti, ki vodi v višjo dodano vrednost izdelkov ali storitev.

Pomemben dejavnik je vodstvo podjetja, saj je od njega odvisno kako spodbuja ustvarjalnost in inovativnost po celotni hierarhiji navzdol vse do delavca in takšna podjetja so običajno bolj konkurenčna gledano tako kratkoročno kot dolgoročno.

\section{Teoretična izhodišča}

Inovativnost $\mathrm{v}$ organizaciji je misel, katera preplavlja vse zaposlene in je vključena $\mathrm{v}$ del procesa organizacije. Kot temelj inovativnosti ali ustvarjanja je vsekakor znanje, le ta pa mora prehajati med zaposlenimi in je zanj zelo pomembna sodelovalna klima, katera je pogoj, da so zaposleni pripravljeni deliti znanje. Proizvodi, storitev ali proces mora predstavljati za odjemalca ali uporabnika nekaj novejšega, boljšega, ni pa nujno, da je na trgu novo - novo je tisto, kar je kakovostno različno od obstoječega. (Likar, 2001, str. 58)

Šega (2019, str. 88-89) pravi, da so organizacije, katerih vodje, kot ostali zaposleni, kateri se zavedajo pomembnosti spodbujanja ustvarjalnosti in inovativnosti, so dosti bolj konkurenčne tako na kratki kot na dolgi rok.

Kos (1996, str. 21) opredeljuje meje inovacije s procesnimi razsežnostmi. Inovacijski proces po njegovem mnenju obsega naslednje faze (ideja, odkritje, raziskovanje, razvoj, izum, uvajanje novega proizvoda na trg, tekoče ovrednotenje).

Inovativno podjetje $\mathrm{v}$ smislu obvladovanja sprememb opredeljuje tudi Drucker (Drucker 2007, str. 51). Organizacije v družbi znanja pri svojem delovanju spreminjajo znanje v dodano vrednost proizvodov in storitev preko izboljšav v proizvodnji in stalnem inoviranju. Svoj način delovanja prilagajajo upravljanju sprememb in inoviranju, v svojo lastno strukturo vpeljujejo menedžment sprememb. Naravnane so k sistematičnemu opuščanju uveljavljenih, 
Marec 2021, leto / year 10, številka / number 1, str. / pp. 26-40.

običajnih proizvodov, storitev in procesov, medosebnih odnosov in organizacijskih struktur, ustvarjanju novih ter izboljševanju obstoječih.

Podobnik (2009, str. 8) pravi, da je inovativno vodenje vpliva na notranje organizacijske dejavnike spodbude za inoviranje: organizacijsko kulturo, organizacijsko strukturo in sistem nagrajevanje, hkrati pa na inovacijsko vodenje vpliva velikost podjetja.

Ilič (2002, str. 24-25) meni, da inovacije niso samo novi izdelki in storitve, ampak tudi tehnične izboljšave, ki predstavljajo mehanizem za znižanje stroškov. Inovacije so lahko tudi organizacijske. Pri tem gre zlasti za spremembe organizacijske strukture oziroma organizacije proizvodnega procesa.

Po Bergincu (2001, str. 169) obstajajo štirje tipi inovacij: izdelek, proces, marketing in menedžment. Izdelana inovacija pomeni nov izdelek ali storitev ali izboljšanje starega izdelka ali storitve. Procesna inovacija pomeni izboljševanje procesov znotraj organizacije, na primer pri upravljanju s človeškimi vir ali financah. Osredotoča se na povečanje učinkovitosti. Marketinška inovacija je povezana s trženjskim spletom - promocijo, cenami in distribucijo kot tudi z drugimi funkcijami izdelka, na primer: embalažo ali oglaševanjem. Menedžerska (upravljavska) inovacija izboljša način vodenja podjetja.

Hojč (2019, str. 174) piše, da vsaka ideja, če se zdi še tako "slaba" je vredna vsaj, da se jo pregleda. Vsako dobro idejo pa je potrebno konkretno analizirat in čim prej vpeljati v proces. Ko se izkaže za koristno in učinkovito, je potrebno lastnika ideje primerno nagraditi in ga motivirat, da še naprej delje v korist podjetja in podaja ideje. Nikakor pa se ne sme zanemariti dejstva, da vsaka ideja le ni dobra. Potrebno je, da podjetje ustrezno daje povratne informacije zaposlenim, v katero stran se naj usmerijo pri iskanju idej in izboljšav.

V svojem magisterskem delu Guštin (2006, str. 5) navaja, da v sodobnih organizacijah dobiva ustvarjalnost vse bolj pomembno vlogo. Tako lastniki kot menedžment ugotavljajo, da je potrebno ustavrjalnost vseh zaposlenih spodbujati in aktivirati in kar je še pomembnotudi meriti. Ustvarjalni potencial je potrebno prepoznati $\mathrm{v}$ vsakem posamezniku in ne le ozki skupini izbrancev. To nas lahko pripelje do skupnih sinergij in nujne celovitosti ustvarjalnih dosežkov poslovnih in drugih dejanj.

Vse bolj se moramo zavedati, da je ustvarjalnost ena izmed možnosti za povečanje inovativnosti, kar lahko izboljša samo poslovanje podjetja. To je še ena izmed najlažjih in ugodnejših rešitev za izboljšavo izdelkov v primerjavi z vpeljevanjem novih tehnologij. (Kligl, 2010, str. 2)

Ustvarjalne ideje so jedro vsakega podjetja, le to pa so priložnost za zaposlene organizacijo in tudi družbo. Potrebno je ustvariti organizacijsko kulturo, ki spodbuja inovativnost. Od zaposlenih pa se zahteva predvsem komunikativnost, znanje in kakovostne medsebojne odnose, ki so temelj za dobre skupne rezultate. Ustvarjati morajo bolše proizvode, iskati lažje 
Marec 2021, leto / year 10, številka / number 1, str. / pp. 26-40.

in izvirnejše poti ter neprestano izboljševati tehnologijo in posodabljati proizvodnjo. (Kranjc, 2013, str. 3)

Bijek (2019, str 179-192) omenja, da, vse več študij navaja pomembnost timskega dela. Timsko delo je učinkovitejše in kakovostno. V timu pa morajo sodelovati zaposleni, ki delajo za skupni cilj in ne cilj posameznika. Takšni timi sktivajo ogromo neodkritih potencialov, ki pa jih zaradi različnih razlogov nikoli ne izkoristimo. Dejstvo je, da tim sestavljajo različni zaposlenimi, ki imajo prav tako različne kompitence in izkušnje, ki prinašajo paleto različnih znanj in izkušenj, kar pripomore k lažji, hitrejši in kakovosnejši rešitvi.

S pomočjo raziskave želimo potrditi tezo, da spodbujanje ustvarjalnosti in inovativnosti, kot eden izmed temeljnih gradnikov odličnosti EFQM, ustvarja višjo vrednost, ter boljše rezultate v organizacijah.

Poznamo naslednjih osem temelnjnih gradnikov modela odličnosti EFQM, ki so (FOŠmeter poslovne odličnosti, 2020):

- dodajanje vrednosti za odjemalce,

- ustvarjanje trajnostne prihodnosti,

- razvijanje sposobnosti organizacije,

- spodbujanje ustvarjalnosti in inovativnosti,

- vodenje $\mathrm{z}$ vizijo, navdihom in integriteto,

- agilni menedžment,

- doseganje uspehov z nadarjenostjo zaposlenih,

- trajno doseganje izvrstnih rezultatov.

Temeljni gradnik modela odličnosti EFQM - Spodbujanje ustvarjalnosti in odličnosti (FOŠmeter poslovne odličnosti, 2020):

- odlične organizacije ustvarjajo višjo vrednost in raven uspešnosti svojega delovanja s stalnim izboljševanjem in sistematičnim inoviranjem, tako da izkoristijo ustvarjalnost svojih deležnikov

- uvajajo načine za vključevanje relevantnih deležnikov ter uporabljajo njihovo skupno znanje pri ustvarjanju idej in inovacij ,

- vzpostavljajo in obvladujejo učne mreže in mreže za sodelovanje, da bi prepoznale priložnosti za ustvarjalnost, inovacije in izboljšave

- se zavedajo, da inoviranje lahko velja za izdelke, procese, trženje, organizacijske strukture in poslovne modele

- na podlagi razumevanja trga in priložnosti postavljajo jasne cilje za inoviranje, podprte $\mathrm{z}$ ustreznimi politikami in viri

- uporabljajo strukturiran pristop za ustvarjanje in prednostno razvrščanje ustvarjalnih idej

- preizkušajo in izboljšujejo najobetavnejše ideje in jim namenjajo sredstva za uresničitev v primernih časovnih okvirih 
- uresničujejo ideje v časovnih okvirih, ki omogočajo maksimizirati dosežene prednosti.

\section{Metoda}

$\mathrm{Na}$ osnovi pridobljenih teoretičnih izhodišč smo si nadalje zastavili raziskovalno vprašanje in temu primerno izdelali model raziskave.

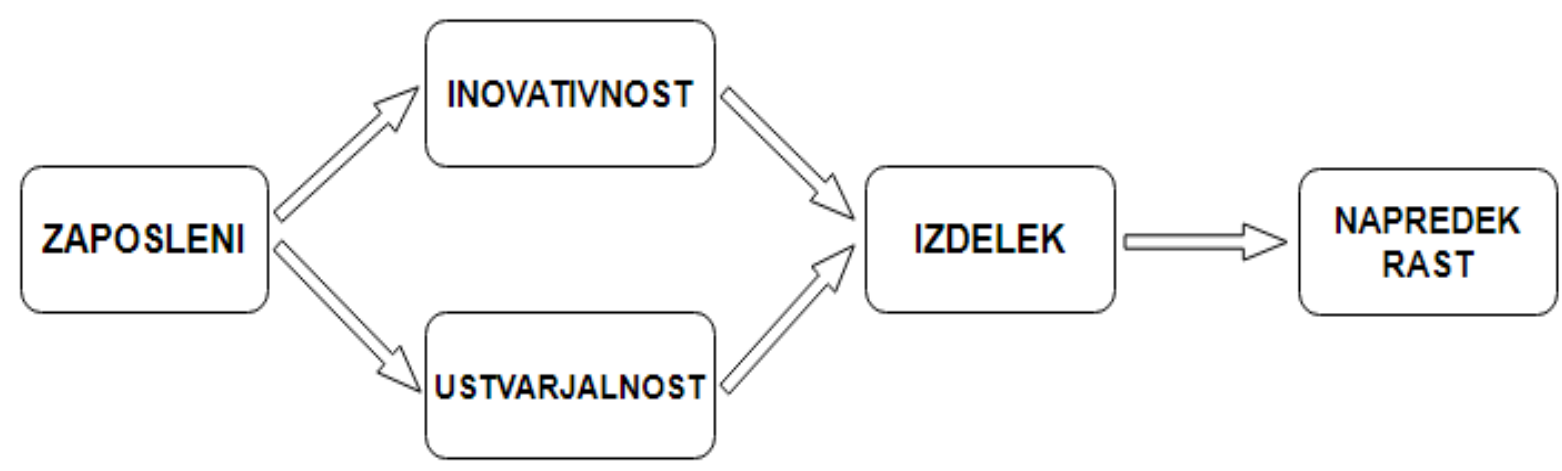

Slika 1. Model raziskave

Model raziskave ponazarja sinhrono korelacijo ustvarjalnosti in inovativnosti na izdelek, kateri vpliva na napredek in rast podjetja, kar pa pozitivno vpliva na konkurenčnost na trgu. Torej, izdelek mora biti privlačen za potrošnike in konkurenčen izdelkom ostalih proizvajalcev na trgu. V končni fazi je od njega odvisen napredek in rast ter v končni fazi lahko tudi uspeh podjetja. Model raziskave tudi nazorno prikazuje, kako zaposleni s svojo ustvarjalnostjo in inovativnostjo vplivajo na izdelek, ki je nedvomno osrednji element poslovanja podjetja.

Za potrebe raziskave smo uporabili metodo kvalitativne analize, ki temelji na vsebinski analizi vprašanj $\mathrm{v}$ raziskavi. Iz analize smo dobili rezultate raziskave, ki se nanašajo na ustvarjalnost in inovativnost zaposlenih. Na osnovi različnih odgovorov na posamezni pogradnik smo določili povprečno oceno dotičnega podgradnika, ter ga zapisali v tabelo. Na koncu smo pridobili še povprečno vrednost podgradnika spodbujanje ustvarjalnosti in inovativnosti.

Iskanje virov na temo ustvarjalnost in inovativnost je potekalo v digitalni knjižnici FOŠ, knjižnici univerze v Mariboru ter v Google Učenjaku. Pri iskanju smo uporabili ključni besedi ustvarjalnost in inovativnost. Uporabili smo literaturo domačih ter tujih avtorjev in izdelali tabelo s seznamom avtorjev in njihovih strokovnih del. 
Marec 2021, leto / year 10, številka / number 1, str. / pp. 26-40.

Tabela 1. Seznam avtorjev in uporabljene literature

\begin{tabular}{ll}
\hline Avtor (letnica) & Naslov \\
\hline Berginc, J. (2001) & Ustvarjalnost in inovativnost v podjetju. \\
Bijek, L. (2019) & Odnosi, komunikacija, motivacija in nagrajevanje kot dejavniki. \\
Drucker, P. (2007) & Inovation and entrepeneurship: practic and principles. \\
Guštin, N. (2006) & Aktiviranje ustvarjalnosti za večjo inovativnost poslovanja. \\
Hojč, D. (2019) & Model vpliva dodane vrednosti za inoviranje v podjetju. \\
Ilič, B. (2002) & Sociekonomska analiza spodbude za inoviranje v podjetju. \\
Kligl, A. (2010) & Ustvarjalnost in inovativnost slovenskih podjetij. \\
Kos, M. (1996) & Inovacijski menedžment. \\
Kranjc, D. (2013) & Ustvarjalnost, kot pogoj za inovativnost. \\
Likar, B. (2001) & Inoviranje. \\
Podobnik, N. (2009) & Notranje organizacijske spodbude za inovativnost v podjetjih. \\
Šega, M. (2019) & Karakteristike vodij za spodbujanje ustvarjalnosti in inovativnosti v organizaciji. \\
\hline
\end{tabular}

Vso uporabljeno literaturo, ki je predstavljena $\mathrm{v}$ tabeli 1, smo preučili in iz nje izluščili bistvene ugotovitve na temo ustvarjalnost in inovativnost posameznih avtorjev strokovnih del in so navedeni v teoretičnih izhodiščih.

Omeniti je potrebno, da smo v raziskovalnem delu članka uporabili tudi preglednico ocen FOŠmeter poslovne odličnosti - preglednica ocen, ki povzema rezultate samoocenitve matičnih organizacij udeležencev Poletne šole FOŠ »Poslovna odličnost« in sicer 20 za leto 2018 in 49 za leto 2020.

Samoocenitev poslovne odličnosti je bila izvedena po metodologiji, ki jo je razvila Fakulteta za organizacijske študije $v$ Novem mestu in temelji na modelu odličnosti EFQM. FOŠmeter poslovne odličnosti za vsakega od osmih gradnikov odličnosti podaja opise usmeritvenih trditev, pri čemer je bila za potrebe samoocenitve stopnja doseganja stanja vrednotena $\mathrm{V}$ razponu od 0 do 5 kot to predvideva metodologija modela CAF (Commmon Assesement Framework).

Naša ocenitev lastne organizacij je bila na podobni ravni, zato navajamo le rezultate samoocenitve.

\section{Rezultati in razprava}

\subsection{Raziskava gradnika odličnosti}

Skozi študijo člankov smo $\mathrm{v}$ tabeli 2. ugotovitve iz analizirane literature, zbrali najpomembnejše ugotovitve avtorjev pri razlagi ustvarjalnosti in inovativnosti $\mathrm{v}$ organizacijah, ter kaj je potrebo storiti, da dosežemo EFQM odličnost v tem. 
Marec 2021, leto / year 10, številka / number 1, str. / pp. 26-40.

Tabela 2. Ugotovitve iz analizirane literature

\begin{tabular}{|c|c|}
\hline Avtor & Ugotovitve \\
\hline Berginc, J. (2001) & Štirje tipi inovacij: izdelek, proces, marketing in menedžment. \\
\hline Bijek, L. (2019) & $\begin{array}{l}\text { Pomembnost timskega dela, ki je učinkovitejše in kakovostnejše. Sodelujoči v timih } \\
\text { imajo različna znanja in izkušnje kar pripomore k boljšim rezultatom. }\end{array}$ \\
\hline Drucker, P. (2007) & $\begin{array}{l}\text { V ospredju je znanje_kot najpomembnejši proizvodni dejavnik. Sprejemati hitre } \\
\text { odločitve, se prilagajati, biti na tekočem s tehnologijo, trgom, spremembami v družbi, } \\
\text { okoljem znanjem, kar se izraža v izkoriščanju priložnosti za inoviranje. }\end{array}$ \\
\hline Guštin, N. (2006) & $\begin{array}{l}\text { Lastniki in menedžment se vedno bolj zavedajo, da je ustvarjalnost zaposlenih } \\
\text { potrebno obravnavati, meriti, aktivirati in spodbujati, tudi z večjo mero uporabe tehnik } \\
\text { spodbujanja in aktiviranja ustvarjalnosti. }\end{array}$ \\
\hline Hojč, D. (2019) & $\begin{array}{l}\text { Vsaka ideja, tudi "slaba" je vredna vsaj pregleda. Dobro idejo konkretno analizirat in } \\
\text { vpeljati v proces. Lastnika ideje je potrebno primerno nagraditi in ga motivirat. } \\
\text { Potrebne povratne informacije zaposlenim, kam se usmeriti pri iskanju idej, izboljšav. }\end{array}$ \\
\hline Ilič, B. (2002) & $\begin{array}{l}\text { Inovacije niso samo novi izdelki in storitve so tudi tehnične izboljšave in tudi } \\
\text { organizacijske. }\end{array}$ \\
\hline Kligl, A. (2010) & $\begin{array}{l}\text { Ustvarjalnost in inovativnost sta povezana pojma in v današnjih razmerah predstavljata } \\
\text { velik pomen za podjetja. Podjetja, ki želijo v današnjih konkurenčnih razmerah preživeti } \\
\text { morajo čim več delati na inovativnosti podjetja in ustvarjalnosti zaposlenih. }\end{array}$ \\
\hline Kos, M. (1996) & Inovacija je namreč pojem, ki ima mnoge definicije in se uporablja na veliko področjih. \\
\hline Kranjc, D. (2013) & $\begin{array}{l}\text { Ustvarjalne ideje so jedro vsake organizacije. Ideje so priložnost za zaposlene, za } \\
\text { organizacijo in celotno družbo. Vsakdo ima ustvarjalni potencial, vendar je potrebno } \\
\text { večino ljudi spodbuditi, da ga izrazijo. Zato mora organizacija ustvariti takšno } \\
\text { organizacijsko kulturo, ki bo naklonjena ustvarjanju inovacij. }\end{array}$ \\
\hline Likar, B. (2001) & $\begin{array}{l}\text { Inovativnost } \mathbf{v} \text { organizaciji je misel, katera preplavlja vse zaposlene in je vključena v } \\
\text { del procesa organizacije. }\end{array}$ \\
\hline Podobnik, N. (2009) & $\begin{array}{l}\text { Inovativno vodenje vpliva na organizacijsko kulturo, organizacijsko strukturo in sistem } \\
\text { nagrajevanje. }\end{array}$ \\
\hline Šega, M. (2019) & $\begin{array}{l}\text { Dober vodja mora imeti dobro razvit čut za timsko delo, biti mora samozavesten in } \\
\text { prepričljiv. Znati mora ostati miren v vseh situacijah, saj mu bodo zaposleni le tako } \\
\text { zaupali. Dober vodja mora biti dober komunikator in usmerjevalec. }\end{array}$ \\
\hline
\end{tabular}

Za boljšo preglednost $\mathrm{v}$ tabeli 2 . ugotovitve in analiziranje literature, smo ključne besede $\mathrm{v}$ ugotovitvah odebelili. Iz njih smo sestavili glavne značilnosti posameznih avtorje, katere smo v nadaljevanju tudi povzeli.

Pri pregledu literature smo ugotovili, da vsi avtorji dajejo velik pomen ustvarjalnosti in inovativnosti. Interpretacija inovacije se med avtorji nekoliko razlikujejo vendar imajo vsi enako nit - pripomore k boljšim rezultatom. Berginc J. (2001) navaja štiri tipe inovacij, kot so izdelek, proces, marketing in menedžment medtem, ko Ilič B. (2002) omenja, da inovacije niso samo novi izdelki in storitve, ampak so tudi tehnične in organizacijske izboljšave. Za Kos M. (1996) pa je inovacija namreč pojem, ki ima mnogo definicij in se uporablja na veliko različnih področjih.

Omeniti je potrebno, da $\mathrm{k}$ boljšim rezultatom doseganja ustvarjalnosti in inovativnosti vpliva veliko različnih dejavnikov. Bijek L. (20219) navaja pomembnost timskega dela, medtem, ko Drucker P. (2007) daje v ospredje znanje in sprejemanje hitrih odločitev. Potrebno se je tudi prilagati in biti na tekočem na različnih področjih, kot so napredna tehnologija, zahteve trga, spremembe v družbi, okoljem ..., v tem pa vidi tudi priložnosti za inoviranje. 
Marec 2021, leto / year 10, številka / number 1, str. / pp. 26-40.

Guštin N. (2006) je mnenja, da se lastniki in menedžment vse bolj zavedajo ustvarjalnosti zaposlenih, katero je potrebno aktivirati in spodbujati in na koncu tudi meriti. Tudi Kligl A. (2010) navaja, da je potrebno čim več delati na ustvarjalnost in inovativnost podjetja in s tem preživeti v današnjih konkurenčnih razmerah.

Za organizacijo je pomembno, da ustvari organizacijsko kulturo, ki bo naklonjena ustvarjanju inovacij. Poleg tega še Kranjc D. (2013) opozarja, da so ideje priložnosti tako za zaposlene kot za podjetje in je ustvarjanje idej jedro vsake organizacije.

Da je ustvarjalnost in inovativnost možno povezana $\mathrm{z}$ vodenjem sta mnenja avtorja Podobnik N. (2009) in Šega M. (2019). Pomembnost dobrega vodje je čut za timsko delo, prepričljivost in mirnost v vseh situacijah. Če to vodja ima mu bodo zaposleni zaupali in jih bo lahko njihov usmerjevalec.

Ena izmed najzanimivejših in v praksi preverjenih trditev se mi zdi od Hojč D. (2019), da je vsaka ideja tudi slaba ideja vredna vsaj pregleda, seveda pa je potrebno dobro idejo konkretno analizirati in čim hitreje vpeljati v proces. Ne smemo pa pozabiti, da je potrebno lastnika primerno nagraditi in ga motivirati še za naprej.

Ljudje smo generatorji sprememb, nosilci napredka in izboljšav. S svojim edinstvenim znanjem, ustvarjalnostjo in idejami dodajamo vrednost izdelkom in storitvam, premagujemo ovire, premikamo meje možnega ter pripomoremo $\mathrm{k}$ doseganju rezultatov. $\mathrm{Z}$ načinom vodenja udejanjamo odprto organizacijsko kulturo, sproščanje potencialov in idej. Ustvarjalnost in inovativnost sta povezana pojma in $\mathrm{v}$ današnjih razmerah predstavljata velik pomen za podjetja. Doseganje poslovne odličnosti pomeni dosegati trajnostne, izjemne, nadpovprečne rezultate na uravnotežen način. Pomeni dosegati odlične rezultate tudi pri svojih zaposlenih, odjemalcih, partnerjih, družbenem okolju in posledično tudi pri finančnih rezultatih. Podjetja, ki želijo v današnjih konkurenčnih razmerah preživeti morajo čim več delati na inovativnosti podjetja in ustvarjalnosti zaposlenih.

\subsection{Analiza gradnika po FOŠmetru poslovne odličnosti}

Spodnja tabela 3. nam prikazuje pridobljene rezultate raziskave gradnika spodbujanje ustvarjalnosti in inovativnosti po FOŠmetru poslovne odločnosti, udeležencev poletne šole FOŠ »Poslovna odličnost« in sicer 20 za leto 2018 in 49 za leto 2020. 


\begin{tabular}{|c|c|c|c|c|}
\hline $\begin{array}{l}\text { Zap. } \\
\text { št. }\end{array}$ & $\begin{array}{l}\text { SPODBUJANJE USTVARJALNOSTI IN } \\
\text { INOVATIVNOSTI }\end{array}$ & $\begin{array}{l}\text { Povprečje } \\
\quad 2018\end{array}$ & $\begin{array}{l}\text { Povprečje } \\
2020\end{array}$ & $\begin{array}{l}\text { Skupno } 2018 \\
\text { in } 2020\end{array}$ \\
\hline 1 & $\begin{array}{l}\text { uvajajo načine za vključevanje relevantnih deležnikov ter } \\
\text { uporabljajo njihovo skupno znanje pri ustvarjanju idej in } \\
\text { inovacij; }\end{array}$ & 3,80 & 3,33 & 3,46 \\
\hline 2 & $\begin{array}{l}\text { vzpostavljajo in obvladujejo učne mreže in mreže za } \\
\text { sodelovanje, da bi prepoznale priložnosti za ustvarjalnost, } \\
\text { inovacije in izboljšave; }\end{array}$ & 3,85 & 3,65 & 3,71 \\
\hline 3 & $\begin{array}{l}\text { se zavedajo, da inoviranje lahko velja za izdelke, procese, } \\
\text { trženje, organizacijske strukture in poslovne modele; }\end{array}$ & 4,10 & $\underline{3,92}$ & 3,97 \\
\hline 4 & $\begin{array}{l}\text { na podlagi razumevanja trga in priložnosti postavljajo jasne } \\
\text { cilje za inoviranje, podprte z ustreznimi politikami in viri; }\end{array}$ & 4,05 & 3,69 & 3,80 \\
\hline 5 & $\begin{array}{l}\text { uporabljajo strukturiran pristop za ustvarjanje in prednostno } \\
\text { razvrščanje ustvarjalnih idej; }\end{array}$ & 3,85 & 3,20 & 3,39 \\
\hline 6 & $\begin{array}{l}\text { preizkušajo in izboljšujejo najobetavnejše ideje in jim } \\
\text { namenjajo sredstva za uresničitev v primernih časovnih } \\
\text { okvirih; }\end{array}$ & $\underline{4,35}$ & 3,71 & 3,90 \\
\hline \multirow[t]{2}{*}{7} & $\begin{array}{l}\text { uresničujejo ideje v časovnih okvirih, ki omogočajo } \\
\text { maksimizirati dosežene prednosti. }\end{array}$ & 4,10 & 3,73 & 3,84 \\
\hline & povprečje & 4,01 & 3,61 & 3,72 \\
\hline
\end{tabular}

Poslovno leto 2018 je bilo najuspešnejše leto s skupno povprečno oceno 4,01. Z doseženo oceno so lahko zadovoljni, saj njen rezultat potrjuje ustrezno zastavljene aktivnosti. Aktivnosti kažejo pravo pot k odličnosti. Podgradnik 1 je prejel najslabšo povprečno oceno, ki znaša 3,8 kar pomeni, da bi morali na tem področju več pozornosti nameniti vključevanju relativnih deležnikov in uporabljati skupno znanje pri ustvarjanju idej in inovacij. Ta aktivnost bi pripomogla $\mathrm{k}$ boljši oceni podgradnika, kot tudi skupni oceni. Prav tako je potrebno izboljšati rezultate podgradnika 2. Vzpostavljajo in obvladujejo učne mreže in mreže za sodelovanje, da bi prepoznale priložnosti za ustvarjalnost, inovacije in izboljšave ter podgradnika 5. Uporabljajo strukturiran pristop za ustvarjanje in prednostno razvrščanje ustvarjalnih idej, saj je njuna ocen pod 4.

Vsak podgradnik je enakovredno pomemben za spodbujanje ustvarjalnosti in inovativnosti, zato se je potrebno ukvarjati z vsemi. Podgradnik 6 je najboljše ocenjen in je zelo pomemben, saj z njim preizkušamo in izboljšujemo najobetavnejše ideje. Temu bi lahko rekli, da gradnik uspešno obvladujejo. Paretovo načelo 20/80 ugotovitev je, da so gospodarni.

V letu 2020 so se ocene spremenile in so se v primerjavi s letom 2018 poslabšale iz 4,01 na 3,61 kar pomeni za 0,4 odstotne točke. Ta rezultat vsekakor ni spodbuden za podjetje, saj je trend negativen. Kot lahko opazimo so vse ocene podgradnikov slabše v primerjavi s letom 2018. Podgradnik 2 je najslabše ocenjen podgradnik v letu in znaša 3,2. Na tem področju so močno nazadovali, ker nimajo dovolj strukturiranega pristopa in jim beži nadzor nad prednostnim razvrščanjem idej. Izgubljajo dragoceni čas z nepotrebnimi idejami, katere niso najbolj dobičkonosne. 
Marec 2021, leto / year 10, številka / number 1, str. / pp. 26-40.

Če pogledamo podgradnik 3 imajo najboljšo oceno 3,92, kar pomeni, da se zavedajo, da lahko inovirajo na večjih področjih, kar jim lahko prinese tudi več izboljšav. Po rezultatih sodeč so naredili korak nazaj v primerjavi s letom 2018, kar pomeni, da morajo analizirati zadevo in pripraviti aktivnosti za izboljšavo.

Omeniti je potrebno, da je skupno povprečje ocen gradnika Spodbujanje ustvarjalnosti in inovativnosti 3,72. Rezultat še ni kritičen, njih pa opozarja, da nekaj ne delajo dovolj dobro in je čas za temeljito analiziranje.

Najboljše ocenjen je podgradnik 3 z oceno 3,97. Tukaj lahko rečemo, da se zavedajo širokega spektra možnosti podajanja inovativnosti, katerega morajo v čim večji meri izkoristiti. Manj so lahko zadovoljni s podgradnik 5, ki je najslabše ocenjen s oceno 3,39. Nikakor ne smejo spregledati nazadovanja v podgradniku 6, kar je zaskrbljujoče, saj se očitno ne ukvarjajo več z najobetavnejšimi idejami ali pa so prepočasni.

$\mathrm{Z}$ ocenami ne smejo biti zadovoljni, ker je trend ustvarjalnosti in inovativnosti negativen. Glede na negativen trend smo podali predloge za izboljšavo:

- analiza obstoječega stanja,

- preučiti proces spodbujanja inovativnosti in ga dopolniti,

- izvesti krožke kakovosti po oddelkih,

- pri osebnih razgovorih z zaposlenimi razložiti pomen inovativnosti za celotno poslovanje podjetja,

- preučiti koncept nagrajevanja inovativnih predlogov.

Menedžment mora ponovno spodbuditi vse zaposlene in jim predstaviti strategijo podjetja ter sistem inovativnosti. Vsi zaposleni se morajo zavedati pomembnosti ustvarjalnosti in inovativnosti, ker je to pomemben dejavnik uspešnosti podjetja.

\subsection{Analiza gradnika po FOŠmetru poslovne odličnosti lasnega podjetja}

Zanimalo nas je tudi stanje gradnika po FOŠmetru poslovne odličnosti še za lastno podjetje. $\mathrm{V}$ ta namen smo izdelali raziskavo. Potekala je med štirimi različnimi sektorji: kakovost, tehnologija, vzdrževanje in informatika. Vsak vodja sektorja je podal svojo oceno. Na osnovi podanih ocen smo izračunali povprečno oceno za posamezni podgradnik in jo zapisali $\mathrm{v}$ tabelo. 


\begin{tabular}{|c|c|c|}
\hline $\begin{array}{l}\text { Zap. } \\
\text { stt. }\end{array}$ & $\begin{array}{l}\text { SPODBUJANJE USTVARJALNOSTI IN } \\
\text { INOVATIVNOSTI }\end{array}$ & $\begin{array}{c}\text { Ocena } \\
2020\end{array}$ \\
\hline 1 & $\begin{array}{l}\text { uvajajo načine za vključevanje relevantnih deležnikov ter } \\
\text { uporabljajo njihovo skupno znanje pri ustvarjanju idej in } \\
\text { inovacij; }\end{array}$ & 3,75 \\
\hline 2 & $\begin{array}{l}\text { vzpostavljajo in obvladujejo učne mreže in mreže za } \\
\text { sodelovanje, da bi prepoznale priložnosti za ustvarjalnost, } \\
\text { inovacije in izboljšave; }\end{array}$ & 3,50 \\
\hline 3 & $\begin{array}{l}\text { se zavedajo, da inoviranje lahko velja za izdelke, procese, } \\
\text { trženje, organizacijske strukture in poslovne modele; }\end{array}$ & 4,25 \\
\hline 4 & $\begin{array}{l}\text { na podlagi razumevanja trga in priložnosti postavljajo jasne cilje } \\
\text { za inoviranje, podprte z ustreznimi politikami in viri; }\end{array}$ & 3,50 \\
\hline 5 & $\begin{array}{l}\text { uporabljajo strukturiran pristop za ustvarjanje in prednostno } \\
\text { razvrščanje ustvarjalnih idej; }\end{array}$ & 3,25 \\
\hline 6 & $\begin{array}{l}\text { preizkušajo in izboljšujejo najobetavnejše ideje in jim namenjajo } \\
\text { sredstva za uresničitev v primernih časovnih okvirih; }\end{array}$ & 4,00 \\
\hline \multirow[t]{2}{*}{7} & $\begin{array}{l}\text { uresničujejo ideje v časovnih okvirih, ki omogočajo } \\
\text { maksimizirati dosežene prednosti. }\end{array}$ & 3,75 \\
\hline & povprečje & 3,71 \\
\hline
\end{tabular}

Ocene posameznega podgradnika se vidijo iz tebele 4 . Lahko vidimo, da smo najboljše ocenili podgradnik 3 in sicer z ocno 4,25. Najmanj smo lahko zadovoljni z oceno podgranika 5 , kjer ocena znaša samo 3,25 . Z raziskavo smo ugotovili, da je skupna povprečna ocena 3,71 in to za podjetje ni slabo.

Lastno podjetje je aktivna na področju ustvarjalnosti in inovativnosti. Vodstvo strmi k nenehnemu izboljšanju ustvarjalnosti in inovativnosti skozi organizirane sestanke, oziroma sklicane delavnice na to temo. Ustvarjalni potencial vsakega posameznika $v$ organizaciji je izreden, vendar ni izražen, saj so nekateri z velikim številom inovativnih predlogov, nekateri pa jih sploh nimajo. $\mathrm{V}$ ta namen organizacija spodbuja vse $\mathrm{z}$ raznimi letnimi nagradami za področje ustvarjalnosti in inovativnosti. Rezultati raziskave kažejo na izredno sposobnost na področju inoviranja, saj so ocene v zgornji tretjini, vendar so v letu 2020 bili pod pritiskom zunanjih nadčloveških faktorjev kateri so močno vplivali na sposobnost ustvarjalnosti in inoviranja. Torej na inovacijsko kulturo $\mathrm{v}$ nekem podjetju vpliva več dejavnikov in eden izmed njih je bil v letu 2020 od zunaj organizacije zelo moteč (Covid 19). Hkrati pa se lahko organizacija pripravi na podobne moteče dejavnike za v prihodnje, da ne pride do zdrsa na področju ustvarjalnosti in inovativnosti. To je zelo pomembno saj se časi hitro spreminjajo in vpliv različnih oblik motečih faktorjev na organizacijo močno vpliva na ustvarjalnost in inovativnost.

$\mathrm{V}$ podjetju lahko še pospešimo ustvarjalnost in inovativnost $\mathrm{z}$ ustrezno kulturo podjetja ter motivacijami vseh zaposlenih. Zavedati se moramo, da se nove poslovne ideje lahko domisli kdor koli, ki je na tak ali drugačen način povezan $\mathrm{z}$ našim delom. In ves ta potencial moramo znati izkoristit. Inovativni smo lahko tudi, če ne načrtujemo novega izuma, dovolj je že majhna izboljšava produkta ali način izdelave. 
Kako ravnamo z zaposlenimi se kaže $\mathrm{v}$ celotnem podjetju in je tudi zelo pomembno, saj se pozitiven ali negativen odnos vodstva do ustvarjalnosti zelo hitro širi med zaposlenimi in zunanjimi sodelavci. Prav tako se veliko ukvarjamo z izobraževanjem zaposlenih saj je znanje tudi pomemben dejavnik pri ustvarjalnosti in inovativnosti.

V podjetju smo se strateško odločili, da bomo spodbujali in razvijali inovativno dejavnost skozi menedžment idej. To pomeni, da verjamemo, da je vsak zaposlen največji strokovnjak na svojem delovnem mestu ter ima ogromno idej in zamisli. S pravilnim pristopom vodij in dobrim sistemom nagrajevanja želimo, da zaposleni te ideje in zamisli prijavljajo ter jih čim hitreje realiziramo $\mathrm{v}$ praksi in dobimo višje prihodke izdelka ali nižje stroške izdelave proizvoda. V procese odpravljanja izgub so vključeni zaposleni, spodbuja se timsko delo, inovativnost, komunikacija na vseh nivojih, izobraževanja, multi-disciplinarnost posameznika in delovne skupine. Naš moto je »vsi zaposleni v podjetju so potencial in možnost napredka«.

Vsekakor lahko povzamemo, da ima lastno podjetje aktivnosti skoraj na vseh področjih, katere smo $\mathrm{z}$ raziskavami različnih avtorjev ugotovili. To pomeni, da smo na pravi poti $\mathrm{k}$ izboljšanju gradnika.

\section{Zaključek}

Članek je sestavlja več poglavij, ki predstavljajo tako teoretični kot empirični del. Namen teoretičnega dela je bil predstavitev citatov iz knjig avtorjev, ki pišejo na temo ustvarjalnost in inovativnost, ter podati izhodišča $\mathrm{k}$ ustvarjalnosti in inovativnosti za podjetja. $\mathrm{V}$ uvodnem poglavju omenjamo, da organizacija, ki želi biti na trgu učinkovita in uspešna mora znati izkoristit tudi sadove ustvarjalnosti in inovativnosti pri zaposlenih, da je spodbujanje ustvarjalnosti in inovativnosti sicer v organizacijah in podjetjih že dolgo znan fenomen, ki se povezuje $\mathrm{z}$ različnimi koncepti upravljanja in vodenja podjetja, da smo v raziskavi preučili uspešnost organizacije na tem področju. V drugem poglavju smo na kratko naredili pregled literature, zapise raznih avtorjev na temo ustvarjalnost in inovativnost. V poglavju metode smo razvili model raziskave, ter natančno opisali temeljni gradnik Ustvarjalnosti in inovativnosti. Opisali smo raziskavo gradnika odličnosti in naredili povzetke ugotovitve iz analizirane literature. $V$ rezultatih in razpravi smo zapisali raziskave gradnika odličnosti glede na ugotovitve iz analizirane literature, analize gradnika po FOŠmetru iz poletne šole FOŠ »Poslovna odličnost« ter raziskavo lastnega podjetja. V samem zaključku pa smo povzeli celotni članek in podali razmišljanja, omejitve in predloge nadaljnjega raziskovanja.

Pridobljeni podatki poletne šole FOŠ »Poslovna odličnost« in sicer 20 za leto 2018 in 49 za leto 2020 so zapisani $\mathrm{z}$ ocenami po posameznem gradniku ustvarjalnosti in inovativnosti FEQM. 2018 je bilo najuspešnejše leto s skupno povprečno oceno 4,01. Z doseženo oceno so lahko zadovoljni, saj njen rezultat potrjuje ustrezno zastavljene aktivnosti. Aktivnosti kažejo pravo pot k odličnosti. 2020 so se ocene spremenile in so se v primerjavi s letom 2018 poslabšale iz ocene 4,01 na 3,61 kar pomeni za 0,4 odstotne točke. Ta rezultat vsekakor ni spodbuden za podjetje saj je trend negativen. Omeniti je potrebno, da je skupno povprečje 
ocen gradnika Spodbujanje ustvarjalnosti in inovativnosti 3,72. Rezultat še ni kritičen, njih pa opozarja, da nekaj ne delajo dovolj dobro in je čas za temeljito analiziranje. Najboljše ocenjen je podgradnik 4 z oceno 3,97. Tukaj lahko rečemo, da se zavedajo širokega spektra možnosti podajanja inovativnosti, katerega morajo v čim večji meri izkoristiti. Manj so lahko zadovoljni s podgradnik 4, ki je ocenjen samo s oceno 3,39. Ta ocena je najslabša. Nikakor ne smejo spregledati nazadovanja $\mathrm{v}$ podgradniku 4, kar je zaskrbljujoče, saj se očitno ne ukvarjajo več z najobetavnejšimi idejami oziroma so prepočasni.

Pri rezultatih analize lastnega podjetja po FOŠmetru, pa lahko povemo da so le ti v veliko pomoč na področju ustvarjalnosti in inovativnosti. Po drugi strani pa je to neka ocena oz. letni izkaz za nadaljnje odločitve v smeri odličnosti poslovanja, morda za uvedbo izobraževanj na tem področju in nov zagon.

Najbolj je pomembno, da se vodstvo zaveda pomena ustvarjalnosti in spodbujanja inovativnosti. Uporaba uspešnosti in inovativnosti je vsekakor večplastno in v veliki meri vpliva na organizacijo kot tudi na družbo (višja gospodarska korist, razvoj, odlični odnosi v organizaciji, napredek). Vsi zaposleni $\mathrm{v}$ podjetju se morajo prizadevati na področju ustvarjalnosti in inovativnosti, dati vsak svoj prispevek tudi v razmerah kakršne smo priča dan danes. Nič naj jih ne ovira na poti odličnosti.

Raziskavo samo usmerili samo v en gradnik modela odličnosti EFQM, zato bi bilo smiselno raziskavo razširiti še na ostale gradnike.

V kolikor bi želeli še podrobnejšo preučitev podgradnikov spodbujanje ustvarjalnosti in inovativnosti bi bilo smiselno izdelati primerjalne analize različnih podjetij. Na osnovi več podatkov bi še natančneje in učinkoviteje določili posamezne smernice, ki kažejo pot k izboljšavi. V dobrovit podjetja je potrebna analiza vseh osmih gradnikov EFQM, saj le ti prinašajo uspeh podjetja.

\section{Reference}

1. Berginc, J. (2001). Ustvarjalnost in inovativnost v podjetju. Portorož: Visoka strokovna šola.

2. Bijek, L. (2019). Odnosi, komunikacija, motivacija in nagrajevanje kot dejavniki uspešnega tima in organizacije. Revija za univerzalno odličnost, junij, 2019 letnik št.2., str. 179-192.

3. Drucker, P. (2007). Inovation and entrepeneurship: praztic and principles. Amsterdam: Butterworth - Heinemann.

4. Guštin, N. (2006). Aktiviranje ustvarjalnosti za večjo inovativnost poslovanja podjetja. Magistrsko delo. Maribor. Ekonomsko-poslovna fakulteta

5. Hojč, D. (2019). Model vpliva dodane vrednosti za odjemalce ter inovativnost. Revija za univerzalno odličnost, jun. 2019, letnik 8, št.2., str. 174

6. Ilič, B. (2002). Sociekonomska analiza spodbude za inoviranje v podjetju. Ljubljana: Fakulteta za družbene vede. 
Marec 2021, leto / year 10, številka / number 1, str. / pp. 26-40.

7. FOŠmeter poslovne odličnosti. (2020). Preglednica ocen. Novo mesto: Fakulteta za organizacijske študije.

8. Kligl, A. (2010). Ustvarjalnost in inovativnost slovenskih podjetij. Diplomsko delo. Maribor: Ekonomska poslovna fakulteta.

9. Kos, M. (1996). Inovacijski menedžment. Priročnik za mala in velika podjetja. Ljubljana: FDV.

10. Kranjc, D. (2013). Ustvarjalnost kot pogoj za inovativnost. Magistrsko delo. Maribor: Ekonomska poslovna fakulteta.

11. Likar, B. (2001). Inoviranje. Koper: Visoka šola za menedžment.

12. Podobnik, N. (2009). Notranje organizacijske spodbude za inovativnost v podjetjih. Diplomsko delo. Ljubljana: Fakulteta za družbene vede.

13. Šega, M. (2019). Karakteristike vodij za spodbujanje ustvarjalnosti in inovativnosti v organizaciji. Revija za univerzalno odličnost, marec, 2019 letnik št.1., str. 88-89.

$* * *$

Rajko Zakšek je diplomiral na Fakulteti za organizacijske študije smer menedžment kakovosti in si pridobil naziv diplomirani organizator. Zaposlen v Podgorju d.o.o., kot vodja službe tehnološke priprave dela in ima več kot dvajset let delavnih izkušenj.

$* * *$

Bojan Krajnc je diplomiral na Fakulteti za organizacijske študije smer menedžment kakovosti in si pridobil naziv diplomirani organizator. Zaposlen je bil v Podgorju d.o.o., kot analitik kakovosti v službi kakovosti in ima več kot dvajset let delavnih izkušenj.

\section{Abstract: Promoting Creativity and Innovation}

Research Question (RV): Do organizations encourage creativity and innovation, which can have a strong impact on products and business at the same time?

Purpose: Identify and analyze the assessment of the fundamental building block of the EFQM model of excellence - creativi and innovation. Make suggestions for improvment based on the findings.

Method: Using a qualitative method, reviewing professional and scientific literature, using a research method with analytical analysis and extracting the essence and findings from them.

Results: The results showed that organizations have a well-developed innovative and creative activity, but the trend in all evaluation components of the EFQM model of excellence is negative, so we made suggestions for improvements. Also, the assessment of the our company building block is satisfactory. All the professional literature examined llists the main activities needed to continuously improve creativty and innovation in organizations.

Organization: The research has a great impact on organizations, as the assessment of the building blocks of EFQM excellence in the field of creativity and innovation provided a starting point for change.

Society: With the research we want to point out that this area is very important, so it is necessary to invest a lot in it in the future, so that the fruits of creativity and innovation will always bear fruit.

Originality: The contribution of the profession is in the originality of the research. We have not yet seen research on promoting creativity and innovation displayed through the building blocks of EFQM excellence.

Limitations / further research: The survery is limited to only one building block with seven EFQM substructures. It would make sense to make comparative analyzes of different companies. 
Revija za univerzalno odličnost / Journal of Universal Excellence,

GRADNIKI POSLOVNE ODLIČNOSTI

Članek / Article

Marec 2021, leto / year 10, številka / number 1, str. / pp. 26-40.

The impact of creativity and innovation on productivity in an organization could be examined below. organizations.

Keywords: creativity, innovation, organization, innovation, economic benefit, employee satisfaction, employee promotion.

Copyright (c) Rajko ZAKŠEK, Bojan KRAJNC

\section{(c) (†) (?)}

Creative Commons License

This work is licensed under a Creative Commons Attribution-ShareAlike 4.0 International License 